Discussion Paper No. 14-074

\title{
Who is afraid of the
} Asset Quality Review?

\section{Potential Losses and Capital Shortfalls}

in the European Banking System

Thomas Bonczek, Clemens Fuest, and Michael Schröder

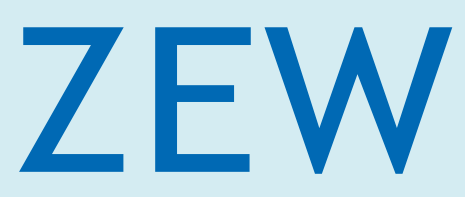

Zentrum für Europäische Wirtschaftsforschung $\mathrm{GmbH}$

Centre for European

Economic Research 
Discussion Paper No. 14-074

\title{
Who is afraid of the Asset Quality Review? \\ Potential Losses and Capital Shortfalls in the European Banking System
}

\author{
Thomas Bonczek, Clemens Fuest, \\ and Michael Schröder
}

Download this ZEW Discussion Paper from our ftp server:

http://ftp.zew.de/pub/zew-docs/dp/dp14074.pdf

Die Discussion Papers dienen einer möglichst schnellen Verbreitung von neueren Forschungsarbeiten des ZEW. Die Beiträge liegen in alleiniger Verantwortung der Autoren und stellen nicht notwendigerweise die Meinung des ZEW dar.

Discussion Papers are intended to make results of ZEW research promptly available to other economists in order to encourage discussion and suggestions for revisions. The authors are solely responsible for the contents which do not necessarily represent the opinion of the ZEW. 


\section{Who is afraid}

\section{of the Asset Quality Review?}

Potential Losses and Capital Shortfalls in the European Banking System

Thomas Bonczek, Clemens Fuest, Michael Schröder 


\section{Authors}

Thomas Bonczek, Yale School of Management and ZEW ${ }^{1}$

Clemens Fuest, University of Mannheim and ZEW

Michael Schröder, Frankfurt School of Finance \& Management and ZEW

The research assistance of Arne Maercker and Melissa Schultheis is gratefully acknowledged.

This version: 25 October 2014

${ }^{1}$ Research contributions of Thomas Bonczek were conducted during his time at the ZEW. 


\section{Contents}

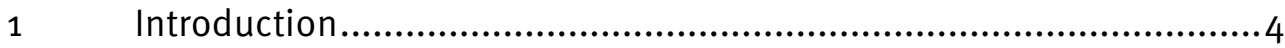

2 The comprehensive assessment and the AQR ..............................9

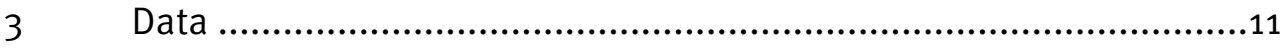

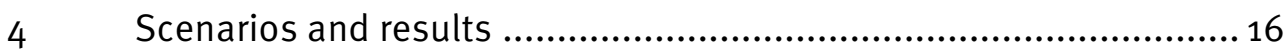

4.1 Unstressed Situation ................................................................. 16

4.2 Writing-off Non-Performing Loans............................................ 21

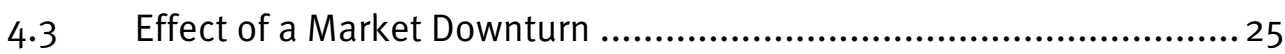

4.4 Effect of a Haircut on Sovereign Debt.........................................2

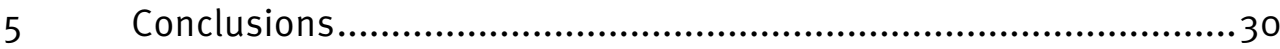

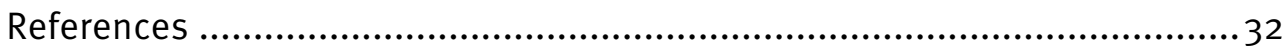

Appendix 
The creation of a banking union is widely seen as a key element of institutional reforms towards more financial and economic stability in Europe. Its objective is to improve the effectiveness of banking regulation and supervision and to sever the link between the finances of national governments and the banks in the Eurozone, which was a destabilising force in the European debt crisis.

A key element of the banking union is the creation of a single supervisory mechanism. At the end of 2014, the European Central Bank will take over the responsibility for banking supervision in the Eurozone. It will directly supervise the largest and systemically most important banks in the Eurozone, a group of approximately 130 financial institutions. Before assuming its new task the ECB intends to investigate the financial solidity of these banks in the framework of a 'comprehensive assessment'. It is the objective of this assessment 'to enhance the transparency of the balance sheets of significant banks in the euro area, and in so doing, to trigger balance sheet repair where necessary, as well as to strengthen confidence.' ${ }^{2}$

The asset quality review (AQR), a review of the quality of different types of assets including underlying collateral will be the most important element of this assessment. The assessment will be combined with a stress test.

The $A Q R$ and the stress test linked to it raise a number of questions. How large will the capital shortfall be? Which banks and which member countries will be affected? How does the type and level of capital thresholds used in the stress test affect the results? How will the required capital be raised? Clearly, the answers to these questions depend on what the ECB and the national authorities participating in the exercise will find in the review. But the

\footnotetext{
2 European Central Bank (2014a), p.1
} 
results will also depend on the structure of bank balance sheets with current valuations. It is therefore interesting to ask whether, on the basis of publicly available information, anything can be said about the magnitude of the existing capital shortfalls ${ }^{3}$ that can be expected. In this paper we calculate hypothetical capital shortfalls by studying various stress test scenarios using publicly available bank balance sheet data.

A related, widely discussed issue is whether banks have already reacted and taken measures addressing capital shortfalls before the review begins. We investigate this by comparing bank balance sheets in 2012 and 2013.

We start with a status quo scenario and calculate the capital shortfall for the common tier 1 (CET1) capital thresholds of 5.5, 8 and $12 \%$ of risk weighted assets as well as book equity to asset ratios of three and four per cent. As a second step, we consider a scenario where $50 \%$ of the currently nonperforming loans have to be written off. Thirdly we assume that, in addition, $5 \%$ of the loans currently classified as performing are reclassified as nonperforming. We then consider a market downturn scenario where specific assets that are held in banks ${ }^{-}$own portfolios (trading securities, assets held for sale, as well as held-to-maturity securities and investments in associates) lose $10 \%$ of their value.

For the analysis of these scenarios we use data from the Bankscope database. Our analysis includes the 128 banks that were originally selected to be covered by the ECBs comprehensive assessment. ${ }^{4}$ For most of these banks

\footnotetext{
3 We define capital shortfalls as the amount of debt funding which would have to be converted to equity to meet capital requirements, keeping the size of the balance sheet stable. An alternative but less straightforward approach would be to calculate the deleveraging which is required to meet the capital thresholds.

4 On September $26^{\text {th }}$ the ECB reported that the number of banks subject to the $A Q R$ is 131 , or 127 banking groups. The full list of the banks included in the AQR is listed in European Central Bank (2014b). See also the corresponding statement on the ECB`s
} 
almost complete balance sheet data are available for 2013. We also conduct the analysis for the year 2012. This allows us to estimate the changes of bank capital and capital shortfalls over the year 2013. As mentioned above, this is interesting because many observers argue that the upcoming AQR has already induced many banks to strengthen their capital base.

In addition, we address the issue of financial stability risks posed by the fact that banks are heavily invested in government bonds. We do so by considering the capital shortfalls that would arise in the case of a restructuring of government debt. Due to data limitations we can only do so for a sample of 49 large Eurozone banks for which the data on sovereign bond holdings is provided by the EBA. These banks still account for about $77 \%$ of the assets of the banks included in the AQR.

Our main findings are as follows. Under current valuations most banks in the Eurozone reach the $8 \% \mathrm{CET}_{1}$ threshold. The Eurozone-wide capital shortfall would only be $660 \mathrm{mn}$ Euros, a very significant reduction compared to the capital shortfall of 15 bn Euros that would exist on the basis of the balance sheet data for 2012. While the CET1 threshold thus leads to a negligible shortfall in 2013 data, things are different if we choose a book-equity-to-asset ratio of $3 \%$ as the relavant benchmark. For this case we find a capital shortfall of 19 bn Euros. But compared to 2012 things have improved here as well. The shortfall for 2012 was much higher (64 bn Euros). More ambitious capital ratios would, unsurprisingly, lead to higher shortfalls.

In the stress scenario, where half of the nonperforming loans are written off, the overall sum of write offs for the large banks in the Eurozone would be about 455 bn Euros, but most of this amount is covered by provisions. To achieve the $8 \% \mathrm{CET}_{1}$ threshold banks would need to raise 12 bn Euros. Again,

website: https://www.ecb.europa.eu/ssm/assessment/html/index.de.html. In our calculations we stick to the 128 banks initially selected to be part of the AQR. 
achieving a book equity to asset ratio of $3 \%$ would be more ambitious and requires 23 bn Euros. Adding $5 \%$ of the loan portfolio to the nonperforming loans that are written off would raise the $3 \%$ book equity shortfall to $56 \mathrm{bn}$, of which 13.1 bn would occur in Dutch banks, 13 bn in French and 12 bn in German banks.

Finally, the market downturn scenario (minus $10 \%$ on banks ${ }^{\prime}$ own portfolios) would lead to a capital shortfall of 154 bn Euros for the 8\% CET1 threshold and 167 bn Euros for the $3 \%$ book equity to asset ratio. This time the highest capital shortfall (regarding the book equity ratio) would be that of Germany with 67 bn Euros followed by France $(54$ bn). For a $4 \%$ book equity to asset ratio, the overall capital shortfall increases to 306 bn Euros.

Our analysis shows that, under the relatively benign scenarios considered here, the capital shortfalls that occur relative to the $8 \%$ CET1 threshold are certainly manageable. While write-offs of nonperforming loans are likely to occur, there are considerable provisions that can absorb losses, in particular in Spain and Italy, but also in France. In contrast, using the book equity to asset threshold leads to much higher results for the capital shortfall and these shortfalls would also affect Germany and France.

Regarding the impact of government debt restructurings our results show that many banks are heavily invested in domestic government bonds. But nevertheless, due to relatively high common tier 1 capital most banks would still meet the $8 \%$ benchmark after a haircut of, for example, sovereign debt in Portugal. Even a haircut in a large country would not change this result significantly. For instance, a 40\% haircut on Italian government bonds would cause bank losses in the Eurozone of about 75 bn Euros, but of which 54 bn Euros would only hit Italian banks. The $8 \%$ CET1 benchmark would only lead to a shortfall in Italian banks of about 26 bn Euros.

In the literature, stress tests in the European banking system and the different aspects of banking union have been discussed intensively. The contribu- 
tion most closely related to this paper is Acharya and Steffen (2014). They also use bank balance sheet data to assess bank capital shortfalls for different stress test scenarios. The main difference to this paper is that we consider different and additional scenarios and use more up-to-date data. In particular, Acharya and Steffen (2014) do not look at government bonds exposures. In this regard our paper is complementary to Acharya and Steffen (2014). Our paper uses the 2013 balance sheet data and, in combination with the data for 2012, we are able to show whether and by how much banks improved their capital base over the year 2013 .

As the capital shortfall regarding the CET1 benchmarks and the book equity ratio decreased significantly over the year 2013, banks in the Eurozone must have improved their $\mathrm{CET}_{1}$ ratio as well as reduced their leverage ratio. The (unweighted) average CET1 ratio over all 128 banks increased to $15.4 \%$ in 2013, an increase of more than 2 percentage points over the year. The average book equity ratio also increased, from $6.1 \%$ at the end of 2012 to almost $6.9 \%$ one year later. Banks used different strategies to improve the equity ratios: Many banks chose to reduce risk-weighted and total assets, but there are also quite a few that increased equity.

The rest of this paper is set up as follows. In section 2 we provide a brief description of the ECB's comprehensive assessment of the European banking system. In section 3 we describe the data we are using and provide some descriptive statistics, particularly regarding the changes between the years 2012 and 2013. Section 4 includes the scenarios and the results of our analysis. In section 5 we discuss the findings and the policy conclusions emerging from the analysis. 


\section{The comprehensive assessment and the AQR}

The $A Q R$ aims at assessing the systemic stability of the European banking system by evaluating the adequacy of the equity of the 131 most important European banks. ${ }^{5}$ This evaluation is done in two steps. The first step is the assessment of the status quo. The second step consists of the application of a stress scenario to banks' assets. The results are to show whether banks are able to withstand various crisis scenarios. In both steps the EBA estimates the gap between certain benchmarks for the capital requirements and banks' equity. How banks will react to equity gaps is an open question. Most likely, they would react by a combination of deleveraging and increasing their equity.

Under the stress scenario the following risk categories will be affected: credit risk, market risk, sovereign risk, securitization, and cost of funding. The assets that will be stressed include both the trading book and the banking book. The results of the AQR will be published at the end of October 2014 .

The benchmarks for the capital requirements are $8 \%$ common equity tier 1 (CET1) for the status quo scenario and $5.5 \%$ for the stress scenario. The $8 \%$ CET1-ratio consists of $4.5 \%$ core tier 1 equity, a surcharge of $1 \%$ for systemically important financial institutions, and $2.5 \%$ capital conservation buffer. For the stress scenarios it is assumed that banks are allowed to use the capital conservation buffer completely to compensate for losses. Therefore the minimum capital requirements are reduced to $5.5 \%$ in the crisis scenario.

Our analysis has two aims: first, our results can be interpreted as a prediction of the results of the comprehensive assessment as we conduct a similar investigation on aggregated bank data, albeit without reviewing current asset

\footnotetext{
5 See e.g. European Central Bank (2014a, b) and European Banking Association (2014).
} 
valuation. Second, we intend to provide additional insights into the stability of the banking system by applying stress tests which will not be part of the $A Q R$ (e.g. haircut on the sovereign debt of Portugal, Spain, and Italy), as well as by using additional benchmarks for the capital requirements. And third, we investigate the change of bank risk over time by analyzing both the balance sheet data of 2012 and of 2013.

Obviously, the ECB and the EBA will have much more detailed information on the bank's risk exposure and the quality of the assets. As our study uses only balance sheet data it is based on the (publicly available) information set of informed capital market participants. Therefore our results should be similar to the expectations of these market participants. 
For our analysis we use balance sheet data for 128 banks which will be investigated in the AQR. ${ }^{6}$ For most of these banks almost complete balance sheet data are available from the Bankscope database. For the evaluation of the effects of a haircut on sovereign bonds we restrict our analysis to 49 large European banks for which the EBA provides detailed data on the sovereign bond holdings. The total assets of these 49 banks amount to approximately $77 \%$ of the total assets of the 128 banks which are analyzed throughout the other parts of the study.

The data sample uses balance sheet data until the end of December 2013 for all simulations. For the analysis of the sovereign bond holdings and the consequences of a haircut on sovereign debt the data sample includes information on the breakdown of bond holdings (by bank and by country) until June 30, 2013, but we again use the balance sheet of 2013 to evaluate the effects of a haircut. We are additionally using the balance sheet data for 2012 to show how the situation regarding the stability of banks changed over the course of the year 2013 .

Table $1 \mathrm{~A}$ in the appendix shows the basic financial statistics for all banks included in the $A Q R$ for 2013. The table gives the information on the CET1 ratio (= CET1 relative to risk-weighted assets), the ratio of risk-weighted assets to total assets as well as the ratio of book equity relative to total assets. ${ }^{7}$

\footnotetext{
${ }^{6}$ On September $26^{\text {th }}$ the ECB reported that the number of banks subject to the AQR is 131 , or 127 banking groups. The full list of the banks included in the AQR is listed in European Central Bank (2014b). See also the corresponding statement on the ECB's website: https://www.ecb.europa.eu/ssm/assessment/html/index.de.html. In our calculations we stick to the 128 banks initially selected to be part of the $A Q R$. 7 In Table 2A in the appendix the same data are given for the year 2012.
} 
The median bank has the following characteristics in 2013 (see the following Table 1): total assets are equal to 61.3 bn Euro, the risk-weighted assets are $40.5 \%$ of the total assets, the CET1 ratio is $13.2 \%$, and the book equity amounts to $6.2 \%$ of the total assets.

The comparison between the two years 2013 and 2012 shows that the median bank reduced total assets by 1.9 bn Euro, increased the CET1 ratio by 1.7 and the book equity to assets-ratio by 0.8 percentage points. The ratio of riskweighted to total assets declined by almost 4 percentage points which means a reduction in risk-weighted assets by about 3 bn Euros. Overall, the median bank reduced its assets and improved its equity base.

Table 1: Basic Financial Statistics for the 128 Banks included in the $A Q R$ : Summary Statistics for 2013 and 2012

Assets (= total assets) in million Euro; CET1 is the Common Equity Tier 1 ratio (in \%); RWA = ratio of risk-weighted assets relative to total assets (in \%); Equity = ratio of book equity to total assets (in \%).

\begin{tabular}{|c|c|c|c|c|}
\hline & Assets & RWA & CET1 & Equity \\
\hline \multicolumn{5}{|c|}{2013} \\
\hline Median & 61260 & 40.5 & 13.2 & 6.2 \\
\hline Mean 8 & 179275 & 42.9 & 15.4 & 6.9 \\
\hline Minimum & 567 & 6.7 & 5.8 & 0.1 \\
\hline Maximum & 1800139 & 110.0 & 112.2 & 32.9 \\
\hline \multicolumn{5}{|c|}{2012} \\
\hline Median & 63200 & 44.4 & 11.5 & 5.4 \\
\hline Mean & 199995 & 44.9 & 13.2 & 6.1 \\
\hline Minimum & 485 & 1.4 & -6.7 & $-4 \cdot 3$ \\
\hline Maximum & 2012329 & 110.7 & 116.4 & 35.5 \\
\hline
\end{tabular}

8 The mean is the unweighted average over all banks. 
The comparison of the mean values shows similar changes over the year 2013 regarding the CET1 and the book equity ratios. As the mean value of total assets is significantly higher than the median the distribution of total assets is skewed to the right: Most of the banks exhibit relatively low values for total assets, but the sample also includes a small number of very large banks. Looking at the change of the mean values the reduction of total assets over the year 2013 was a remarkably high 20 bn Euros which was significantly driven by the largest banks in the sample.

Although the mean of the RWA ratio increased over 2013, the mean values of the risk-weighted assets actually decreased by about 4 bn Euros. The increase in the ratio is due to the fact that total assets had even been reduced by a much higher pace.

The minimum and maximum values exhibit a high variation amongst the banks in the sample. For the CET1-ratio and the book equity ratio this difference between the best and the worst banks shrank over the year 2013 and the minimum values increased significantly.

There are also significant differences in the adjustment strategies of the banks between the very large and the smaller banks in Europe. In the following we rank the 128 European banks under consideration by total assets and form two groups: The first group consists of the 10 largest banks and the second group contains the following 118 banks. Both groups represent about $50 \%$ of the total assets of all 128 banks.

As Table 2 reveals the 10 largest banks reduced not only total assets and riskweighted assets over the year 2013. These banks reduced book equity and, to a smaller extent, CET1 as well. The reduction in total and risk-weighted assets is therefore the main adjustment mechanism regarding the improvement of their capital ratios. 
The 118 smaller banks forming group no. 2 diminished total and riskweighted assets as well, but these banks also increased both book equity and CET1 by a significant amount. The consequence is a higher CET1 ratio and a lower leverage.

Table 2: Comparison of Balance-Sheet Adjustments Between 2012 and 2013 by Bank Size

Assets = total assets; $\mathrm{CET}_{1}=$ common equity tier $1 ;$ RWA = risk-weighted assets; Equity $=$ book equity.

\begin{tabular}{|c|c|c|c|c|}
\hline & Assets & RWA & CET1 & Equity \\
\hline \multicolumn{5}{|c|}{ Difference between 2013 and 2012 in million Euro } \\
\hline All 128 Banks & -2252101 & -294831 & +102075 & +30648 \\
\hline $\begin{array}{l}10 \text { Largest } \\
\text { Banks }\end{array}$ & -1211016 & -76656 & -7343 & -22506 \\
\hline $\begin{array}{l}118 \text { "Small- } \\
\text { er” Banks }\end{array}$ & -1041085 & -218175 & +109418 & +53154 \\
\hline \multicolumn{5}{|c|}{ Change between 2013 and 2012 in per cent } \\
\hline All 128 Banks & $-8.9 \%$ & $-3.7 \%$ & $+10.4 \%$ & $+2.6 \%$ \\
\hline $\begin{array}{l}10 \text { Largest } \\
\text { Banks }\end{array}$ & $-9.5 \%$ & $-2.0 \%$ & $-1.5 \%$ & $-3.7 \%$ \\
\hline $\begin{array}{l}118 \text { “Small- } \\
\text { er” Banks }\end{array}$ & $-8.4 \%$ & $-5.3 \%$ & $+22.5 \%$ & $+9.2 \%$ \\
\hline
\end{tabular}

Overall the comparison between 2012 and 2013 leads to the cautious assessment that the stability of the banks under consideration has improved. In section 4.1 an additional analysis of the most significant changes between 2013 and 2012 is conducted on the country level.

A cautious assessment is necessary for at least two reasons. First of all, our analysis is only based on balance sheet data. We do not have access to the more detailed information set on risk exposures and asset quality as is available to the bank supervisors. The second reason is that Bankscope and the 
other data sources we are using do not deliver complete balance sheet information for all of the 128 banks of the AQR. As Table $1 A$ reveals the dataset is partly incomplete for 21 out of these 128 banks. 9 As these 21 banks only represent about $5 \%$ of the total assets of all 128 banks we expect that our analysis is still meaningful and representative.

Table 3A (in the appendix) lists the 49 banks for which we investigate the effects of haircuts on sovereign bonds in Portugal, Spain, and Italy (see section 4.4 for the results of these scenarios). For these very large banks our dataset is almost complete. Only for two banks - one German and one Greek bank - is the dataset to some part incomplete. These 49 banks represent $77 \%$ of the total assets of all banks included in the AQR.

9 The 21 banks (out of 128 banks) for which the dataset is incomplete are from France (6), Luxembourg (4), Spain (3), Germany (3), Latvia (2), as well as Cyprus (1), Greece (1), and Slovenia (1). 


\section{$4 \quad$ Scenarios and results}

The scenarios we simulate aim at investigating the financial stability of the banking system in the Eurozone under different conditions regarding the realization of specific financial risks. As a result of the simulations we calculate capital shortfalls which are likely to occur under the scenario conditions.

To evaluate the results of the simulations we are using several thresholds regarding the relation of book equity to (not-risk weighted) total assets as well as the common equity tier 1 ratio. For the book equity ratio we apply the usual $3 \%$ threshold and, in addition, a slightly more prudent $4 \%$ ratio. ${ }^{10}$ For the CET1 ratio we use three different thresholds: The official value of $8 \%$ for the CET1 ratio for large banks (consisting of $4.5 \%$ core tier 1 plus $2.5 \%$ capital conservation buffer plus a $1 \%$ surcharge for systemically important financial institutions) that is used as the main threshold in the $A Q R$, a threshold of $5.5 \%$ which is used in the AQR to estimate capital shortfalls in the stress scenarios (i.e. $8 \%$ minus the capital conservation buffer), as well as a more prudent ratio of $12 \%$ which is not used in the $A Q R$.

\subsection{Unstressed Situation}

The first scenario evaluates the status quo and shows whether banks fulfil the capital requirements when no specific financial stress will realize. As can be seen from Table 2 most banks in the Eurozone will exhibit no or only a very small CET1 capital shortfall with respect to the $8 \%$ benchmark. The calculated shortfalls for the $12 \%$ benchmark show that particularly Italian and Portu-

\footnotetext{
${ }^{10}$ According to Haldane (2012) a book-equity-to-asset ratio of 4 per cent would have been required for banks to avoid failure in the recent financial crisis, for large banks even 7 per cent.

16
} 
guese, but also German and Austrian banks seem to be more vulnerable than the banks in other countries of the Eurozone.

\section{Table 3: Results for the Status quo Scenario for the End of the Year 2013}

EQ3 and EQ4: Thresholds for the ratio of book equity to not-risk weighted total assets of either 3 or $4 \%$. CET1-5.5, CET1-8, CET1-12: Thresholds for the CET1 ratio of 5.5\% (for stress scenarios only), $8 \%$, and $12 \%$. In million Euro.

\begin{tabular}{|l|l|l|l|l|l|}
\hline & EQ3 & EQ4 & CET1-5.5 & CET1-8 & CET1-12 \\
\hline AUSTRIA & 0 & 0 & 0 & 0 & 2281 \\
\hline BELGIUM & 3039 & 6572 & 0 & 0 & 0 \\
\hline CYPRUS & 60 & 107 & 0 & 0 & 403 \\
\hline ESTONIA & 0 & 0 & 0 & 0 & 0 \\
\hline FINLAND & 0 & 2676 & 0 & 0 & 0 \\
\hline FRANCE & 10526 & 16487 & 0 & 0 & 0 \\
\hline GERMANY & 884 & 14429 & 0 & 0 & 3419 \\
\hline GREECE & 0 & 0 & 0 & 0 & 1130 \\
\hline IRELAND & 2876 & 5821 & 0 & 0 & 195 \\
\hline ITALY & 0 & 1971 & 0 & 661 & 18776 \\
\hline LATVIA & 0 & 0 & 0 & 0 & 0 \\
\hline LUXEMBOURG & 0 & 0 & 0 & 0 & 0 \\
\hline MALTA & 0 & 0 & 0 & 0 & 84 \\
\hline $\begin{array}{l}\text { NETHER- } \\
\text { LANDS }\end{array}$ & 1440 & 5194 & 0 & 0 & 0 \\
\hline PORTUGAL & 0 & 4 & 0 & 0 & 2106 \\
\hline SLOVAKIA & 0 & 0 & 0 & 0 & 0 \\
\hline SLOVENIA & 0 & 0 & 0 & 0 & 0 \\
\hline SPAIN & 412 & 964 & 0 & 0 & 1333 \\
\hline
\end{tabular}


Nevertheless, the situation improved significantly compared to the year 2012 (see Table 4) in which particularly banks in Cyprus, Greece, and Spain still exhibited large capital shortfalls.

Table 4: Results for the Status quo Scenario for the End of the Year 2012

$E_{2}$ and EQ4: Thresholds for the ratio of book equity to not-risk weighted total assets of either 3 or $4 \%$. CET1-5.5, CET1-8, CET1-12: Thresholds for the CET1 ratio of 5.5\% (for stress scenarios only), $8 \%$, and $12 \%$. In million Euro.

\begin{tabular}{|l|l|l|l|l|l|}
\hline & EQ3 & EQ4 & CET1-5.5 & CET1-8 & CET1-12 \\
\hline AUSTRIA & 0 & 0 & 0 & 0 & 2242 \\
\hline BELGIUM & 8789 & 15199 & 0 & 0 & 0 \\
\hline CYPRUS & 595 & 905 & 1057 & 1597 & 2519 \\
\hline ESTONIA & 0 & 0 & 0 & 0 & 0 \\
\hline FINLAND & 979 & 4399 & 0 & 0 & 0 \\
\hline FRANCE & 11738 & 22773 & 0 & 0 & 378 \\
\hline GERMANY & 7577 & 41997 & 0 & 0 & 3650 \\
\hline GREECE & 13319 & 16257 & 7872 & 9485 & 12689 \\
\hline IRELAND & 4601 & 8319 & 0 & 0 & 272 \\
\hline ITALY & 111 & 2428 & 0 & 263 & 15122 \\
\hline LATVIA & 0 & 0 & 0 & 0 & 0 \\
\hline $\begin{array}{l}\text { LUXEM- } \\
\text { BOURG }\end{array}$ & 0 & 0 & 0 & 0 & 0 \\
\hline MALTA & 0 & 0 & 0 & 0 & 152 \\
\hline $\begin{array}{l}\text { NETHER- } \\
\text { LANDS }\end{array}$ & 4021 & 9470 & 0 & 62 & 885 \\
\hline PORTUGAL & 0 & 0 & 0 & 0 & 1943 \\
\hline SLOVAKIA & 0 & 0 & 0 & 0 & 0 \\
\hline SLOVENIA & 0 & 0 & 0 & 0 & 523 \\
\hline SPAIN & 12488 & 18396 & 402 & 4024 & 25918 \\
\hline
\end{tabular}


When looking at the book equity ratios the situation is slightly worse: for 24 out of the 128 banks the book equity is less than $3 \%$ of the total assets. The highest shortfall is to be expected in France ( 10.5 bn), Belgium ( $3.0 \mathrm{bn}$ ) and Ireland (2.8 bn).

But again, compared to the situation at the end of 2012 the book equity ratios of most banks improved significantly. This is particularly true for Greece with a reduction of the book equity shortfall of $-13.3 \mathrm{bn}$, Spain $(-12.1 \mathrm{bn})$, Germany ( -6.7 bn), and Belgium ( -5.8 bn). Only in France, the country with the highest book equity shortfall, there was no significant change in bank risk over the year 2013 .

The improvements in the CET1-ratio and book equity ratio that occurred during 2013 in most countries could be either due to an increase in capital or a reduction in assets or both. To shed more light on the details of the adjustments Table 5 gives the percent changes of these balance sheet positions over the year 2013 .

The countries with the most significant reduction in the book equity shortfall over the year 2013 are Greece, Germany, and Spain. But also in Belgium, the Netherlands, Ireland and Cyprus the book equity ratio improved clearly. In almost all of these countries banks achieved this improvement by reducing total assets. The only exception is Greece where the banks increased total assets but over-compensated the distorting effect by a strong growth in book equity. With the exceptions of the Netherlands and Ireland all of the above mentioned countries also increased book equity. Thus, reducing total assets and increasing book equity was the strategy chosen by most banks.

Regarding the CET1-ratio the situation is more heterogeneous. Most of the banks in the abovementioned countries also improved the ratio of common equity tier 1 to risk-weighted assets to a certain amount and did so by a reduction in risk-weighted assets. But with regard to equity about half of the countries decreased and the other half increased common tier 1-capital. 


\section{Table 5: Change in Assets and Capital over the Year 2013}

Change in total assets, risk-weighted assets, book equity, and common tier 1 capital over the year 2013. In percent of the values of 2012.

\begin{tabular}{|l|l|l|l|l|}
\hline & Total Assets & RW Assets & Book Equity & C Tier 1 \\
\hline AUSTRIA & -6.0 & -0.7 & -8.2 & -4.6 \\
\hline BELGIUM & -19.3 & -24.2 & 1.9 & -1.5 \\
\hline CYPRUS & -43.4 & -37.7 & 113.9 & 223.0 \\
\hline ESTONIA & 2.3 & 48.4 & 5.2 & 12.1 \\
\hline FINLAND & -8.7 & 12.2 & 4.4 & 4.3 \\
\hline FRANCE & -6.0 & 15.3 & 1.7 & 13.8 \\
\hline GERMANY & -14.2 & -26.4 & 3.3 & 1.4 \\
\hline GREECE & 18.4 & 39.6 & Increase 11 & 371.6 \\
\hline IRELAND & -14.8 & -7.5 & -16.4 & -15.8 \\
\hline ITALY & -7.2 & -5.3 & -13.2 & -7.8 \\
\hline LATVIA & 5.0 & -15.2 & 8.9 & 6.4 \\
\hline LUXEMBOURG & -2.9 & 64.6 & 6.3 & 68.2 \\
\hline MALTA & 0.3 & -0.7 & 8.5 & 10.0 \\
\hline NETHERLANDS & -8.6 & 15.0 & -5.5 & -3.1 \\
\hline PORTUGAL & -4.8 & -7.1 & -10.9 & -6.6 \\
\hline SLOVAKIA & 2.1 & -4.3 & 2.6 & 2.9 \\
\hline SLOVENIA & -11.2 & -28.9 & 25.2 & 21.5 \\
\hline SPAIN & -8.6 & -4.6 & 10.2 & -3.1 \\
\hline
\end{tabular}

In those countries with an obvious failure of systemic stability or at least a high threat of instability in 2012 - Cyprus and Greece - CET1 increased impressively. Astonishingly, in Italy, Portugal, and Spain - also countries that were at the brink of systemic crisis - CET1 has been reduced over the year 2013.

${ }_{11}$ The aggregated book equity for the Greek banks was 7258 in 2013 and -1126 in 2012. Due to the negative basis a percent change is not meaningful.

20 
To sum up, in most countries of the Eurozone banks considerably reduced their risk of financial instability. In particular, the book equity to asset ratio has been improved by decreasing total assets as well as increasing book equity. Only in France, a country with a relatively high book equity shortfall in 2012, the situation did show only a minor change over the year 2013. Irrespective of these positive results, the capital buffers do not seem to be very high: The application of the more prudent $4 \%$ book equity benchmark would cause significant shortfalls particularly in France (16.5 bn) and Germany (14.4 $b n)$.

\subsection{Writing-off Non-Performing Loans}

The next scenario we are simulating is the write-off of non-performing loans. We are assuming that $50 \%$ of the non-performing loans are written off and consider existing loan provisions. This is a major difference compared to Acharya/Steffen (2014) who simulate a 100\% write off and do not include the loan provisions into their calculations. As the loan provisions show large differentials amongst the banking sectors of the Eurozone countries, considering the loan provisions not only makes a significant difference in absolute terms but also changes the comparison across countries substantially.

Table 6 summarizes the main results. Focusing on gross-write-offs only, the banking sectors of Italy (111 bn), Spain ( 99 bn), and France (71 bn) would have to bear the largest burden amongst all Eurozone countries. But the results change significantly when the net-write-offs (= write-offs minus loan provisions) are investigated. The ranking of the largest net-write-offs is led by the Spanish banking sector (16.2 bn), followed by Greece (10.8 bn), Germany (8.1 bn) and then Italy $(7.1 \mathrm{bn})$. Compared to 2012 gross-write-offs increased significantly in some countries. The strongest increases are in Italy $(+17.8$ bn), Greece (+ $15.8 \mathrm{bn})$, and Spain (+15.1 bn). However, it is only in Spain that net-write-offs grew remarkably, too $(+13.9 \mathrm{bn})$. In the other two countries higher loan provisions neutralized most of the increase in write-offs. 
Table 6: Writing Off $50 \%$ of Non-Performing Loans (NPL): Additional Capital Shortfalls compared to the Unstressed Scenario

Write-off: minus 50\% of NPL, Net-Write-Off: Write-off minus loan provisions. EQ3 and EQ4: Thresholds for the ratio of book equity to not-risk weighted total assets of either 3 or $4 \%$. CET1-5.5, CET1-8, CET1-12: Thresholds for the CET1 ratio of $5.5 \%$ (for stress scenarios only), 8\%, and 12\%. In million Euro for the year 2013 .

\begin{tabular}{|l|l|l|l|l|l|l|l|}
\hline & $\begin{array}{l}\text { Write- } \\
\text { Off }\end{array}$ & $\begin{array}{l}\text { Net- } \\
\text { Write- } \\
\text { Off }\end{array}$ & EQ3 & EQ4 & $\begin{array}{l}\text { CET1- } \\
\mathbf{5 . 5}\end{array}$ & $\begin{array}{l}\text { CET1- } \\
8\end{array}$ & $\begin{array}{l}\text { CET1- } \\
12\end{array}$ \\
\hline AUSTRIA & 13233 & 386 & 0 & 0 & 0 & 0 & 102 \\
\hline BELGIUM & 8954 & 1190 & 22 & 23 & 0 & 0 & 0 \\
\hline CYPRUS & 4876 & 0 & 0 & 0 & 0 & 0 & -1 \\
\hline ESTONIA & 85 & 10 & 0 & 0 & 0 & 0 & 0 \\
\hline FINLAND & 1261 & 178 & 0 & 171 & 0 & 0 & 0 \\
\hline FRANCE & 71274 & 139 & 135 & 134 & 0 & 0 & 0 \\
\hline GERMANY & 36347 & 8111 & 3041 & 5874 & 597 & 1401 & 4081 \\
\hline GREECE & 43149 & 10785 & 0 & 386 & 38 & 1806 & 5185 \\
\hline IRELAND & 35909 & 0 & 0 & 0 & 0 & 0 & 0 \\
\hline ITALY & 111431 & 7087 & 0 & 495 & 640 & 2968 & 5519 \\
\hline LATVIA & 191 & 0 & 0 & 0 & 0 & 0 & 0 \\
\hline LUX. & 311 & 31 & 0 & 0 & 0 & 0 & 0 \\
\hline MALTA & 238 & 79 & 0 & 0 & 0 & 33 & 70 \\
\hline NET. & 19479 & 4792 & 397 & 735 & 0 & 0 & 5 \\
\hline POR. & 6574 & 0 & 0 & 0 & 0 & 0 & 0 \\
\hline SLOVAKIA & 596 & 0 & 0 & 0 & 0 & 0 & 0 \\
\hline SLOVENIA & 1911 & 0 & 0 & 0 & 0 & 0 & 0 \\
\hline SPAIN & 99040 & 16169 & 478 & 909 & 1753 & 5210 & 12808 \\
\hline
\end{tabular}

The other five columns of Table 6 show the additional capital shortfalls compared to the unstressed scenario which are due to the NPL write-off. These 
additional shortfalls are relatively small and hit only four countries: The most severe mismatch relative to the $8 \%$ CET1 benchmark would realize in Spain (5.2 bn), Italy ( $3 \mathrm{bn})$, Greece (1.8 bn), and Germany (1.4 bn). However, the application of the $5.5 \%$ benchmark which is used in the AQR for stress scenarios does not show any major capital shortfall, with the exception of Spain (1.8 bn).

Compared to the end of 2012 particularly the Greek banking sector significantly reduced the potential capital shortfall under this scenario. In Spain the situation deteriorated strongly with respect to CET1 but improved for book equity. For all other countries the changes over the year 2013 are relatively small.

Looking at the book equity to asset ratio only the German banking sector would show a larger shortfall of 3 bn Euros. But again this seems to be a manageable amount.

The AQR might lead to the result that additional loans have to be assessed as non-performing. To cover this aspect of the AQR we also simulate the effect on bank capital if $5 \%$ of the existing loans will be classified additionally as not performing. Table 7 shows the results for the book equity to asset ratio.

Compared to the unstressed scenario some countries would face an enormous additional capital requirement to meet the $3 \%$ benchmark. The highest book equity shortfall would occur in the Dutch banking sector (11.7 bn), closely followed by the German banking sector (10.9 bn) and the banks in Belgium (3.9 bn). But overall these capital shortfalls do not look as impressive as their counterparts for the year 2012. Particularly in Germany the situation improved clearly as in 2012 the shortfall would have been 15.9 bn Euros higher. Also in Greece and Spain banks now exhibit a much better capital base. Most of this improvement in Germany and Spain stems from a reduction in total assets whereas in Greece higher book equity contributed to the improved situation. 
Table 7: Write Off $50 \%$ of Non-Performing Loans (NPL) plus Classification of additional $5 \%$ of the Loans as Non-Performing: Additional Net-WriteOffs and additional Capital Shortfalls compared to the Unstressed Scenario

Net-Write-Off: Write-off minus loan provisions. EQ3 and EQ4: Thresholds for the ratio of book equity to not-risk weighted total assets of either 3 or $4 \%$. In million Euro for the year 2013.

\begin{tabular}{|l|l|l|l|}
\hline & Net-Write-Off & EQ3 & EQ4 \\
\hline AUSTRIA & 3377 & 0 & 100 \\
\hline BELGIUM & 9656 & 3933 & 5342 \\
\hline CYPRUS & 157 & 85 & 84 \\
\hline ESTONIA & 211 & 0 & 0 \\
\hline FINLAND & 4727 & 2532 & 2873 \\
\hline FRANCE & 49297 & 2447 & 3732 \\
\hline GERMANY & 46215 & 10857 & 27012 \\
\hline GREECE & 14985 & 602 & 1394 \\
\hline IRELAND & 2219 & 97 & 96 \\
\hline ITALY & 25532 & 2973 & 4844 \\
\hline LATVIA & 65 & 0 & 0 \\
\hline LUXEMBOURG & 742 & 0 & 0 \\
\hline MALTA & 221 & 0 & 0 \\
\hline NETHERLANDS & 38615 & 11681 & 22057 \\
\hline PORTUGAL & 363 & 0 & 0 \\
\hline SLOVAKIA & 230 & 0 & 0 \\
\hline SLOVENIA & 69 & 0 & 0 \\
\hline SPAIN & 47807 & 1305 & 5429 \\
\hline & & & \\
\hline
\end{tabular}




\subsection{Effect of a Market Downturn}

A main source of bank risk is a possible decrease in market prices. To approximate the potential losses of banks in the Eurozone caused by deteriorating asset values we simulate a $10 \%$ negative shock to the value of specific assets which the banks are invested in. We use the balance position "Other Earning Assets" and deduct the value of derivatives as well as loans and advances to other banks. The remaining position mainly consists of trading securities, assets held for sale, as well as held-to-maturity securities and investments in associates which are essential parts of the banks' own portfolios.

A downturn of the values of these assets would significantly deteriorate both the CET1 ratios as well as the book equity ratios of banks in almost all countries of the Eurozone. Even when applying the relatively low benchmark of a CET1 ratio of $5.5 \%$ the banks in the Eurozone would have to face - compared to the unstressed scenario - an additional capital shortfall of about $58 \mathrm{bn}$ Euro. Most of this capital shortfall would realize in France ( $33 \mathrm{bn}$ ), Germany (14.4 bn) and Spain ( $7.5 \mathrm{bn})$. Relative to the $8 \%$ CET1-ratio the capital shortfall would even increase to ca. 154 bn Euro across the banks of the Eurozone. Applying this higher threshold the French banking sector would face a shortfall of $75 \mathrm{bn}$, the German of $30 \mathrm{bn}$ and in Italy and Spain the gap in CET1 would be $22 \mathrm{bn}$ and $15.8 \mathrm{bn}$.

When looking at the $3 \%$ book to equity benchmark the countries mentioned above would also rank highest with Germany ( $66 \mathrm{bn}$ ) showing the most significant mismatch followed by France ( $43.8 \mathrm{bn})$ and Spain (11.9 bn). The Netherlands ( $9.1 \mathrm{bn}$ ) and Belgium ( $7.5 \mathrm{bn}$ ) also exhibit a significant shortfall.

But again, compared to 2012 the capitalization of the banks involved in the AQR show a clear improvement. At the end of 2013 the CET1 shortfall (5.5\% benchmark), although still substantial, was 14 bn Euros lower than one year earlier, regarding the $8 \% \mathrm{CET}_{1}$ benchmark the reduction amounts also to 14 
bn Euros. With regard to the 3\% book equity ratio the shortfall decreased from 198 bn (end of 2012) to 147 bn Euros one year later. These results show that bank still have to substantially increase their capital to assets ratios. But the announced $A Q R$ may have already motivated banks to move in the right direction.

Table 8: Results for the Market Downturn Scenario: Additional Capital Shortfalls compared to the Unstressed Scenario

$E_{3}$ and EQ4: Thresholds for the ratio of book equity to not-risk weighted total assets of either 3 or $4 \%$. CET1-5.5, CET1-8, CET1-12: Thresholds for the CET1 ratio of 5.5\% (for stress scenarios only), $8 \%$, and $12 \%$. In million Euro for 2013 .

\begin{tabular}{|l|l|l|l|l|l|}
\hline & EQ3 & EQ4 & CET1-5.5 & CET1-8 & CET1-12 \\
\hline AUSTRIA & 0 & 69 & 2 & 1637 & 9084 \\
\hline BELGIUM & 7513 & 11447 & 332 & 2343 & 8150 \\
\hline CYPRUS & 32 & 32 & 0 & 0 & 436 \\
\hline ESTONIA & 0 & 0 & 0 & 0 & 0 \\
\hline FINLAND & 3978 & 4304 & 0 & 550 & 4105 \\
\hline FRANCE & 43809 & 98283 & 32968 & 75497 & 157204 \\
\hline GERMANY & 66006 & 92474 & 14384 & 30365 & 69502 \\
\hline GREECE & 0 & 489 & 0 & 1609 & 4381 \\
\hline IRELAND & 339 & 335 & 0 & 0 & 4525 \\
\hline ITALY & 4669 & 5454 & 1831 & 22056 & 50158 \\
\hline LATVIA & 57 & 89 & 0 & 0 & 0 \\
\hline LUXEMBOURG & 1 & 382 & 610 & 1127 & 1954 \\
\hline MALTA & 0 & 0 & 42 & 203 & 375 \\
\hline NETHERLANDS & 9094 & 19498 & 0 & 895 & 12720 \\
\hline PORTUGAL & 710 & 1926 & 0 & 1308 & 2407 \\
\hline SLOVAKIA & 0 & 0 & 0 & 0 & 13 \\
\hline SLOVENIA & 0 & 0 & 0 & 0 & 111 \\
\hline SPAIN & 11865 & 17272 & 7492 & 15874 & 57845 \\
\hline
\end{tabular}




\subsection{Effect of a Haircut on Sovereign Debt}

In the last series of simulations we investigate the consequences of a $40 \%$ haircut on sovereign debt in Portugal, Italy, and Spain. In this analysis we include 49 banks out of the set of banks for which the AQR is conducted. For these 49 banks of the Eurozone the EBA provides disaggregated data on the sovereign bond holdings, differentiated by issuing countries and investing banks. The latest update of this data is for June 2013. For these simulations we are using this information provided by the EBA and combine it with the balance sheet data (end of 2013) from the Bankscope database.

A $40 \%$ haircut on the Portuguese sovereign bonds would cause an overall loss of about 8.5 bn across the 49 banks in the Eurozone that are included in our analysis. The capital shortfall with respect to the $3 \%$ book equity ratio would be relatively small ( 0.6 bn) and would only hit Portuguese banks. The same haircut on Italian and Spanish sovereign bonds would cause significantly higher capital shortfalls. With respect to the $8 \% \mathrm{CET}_{1}$ benchmark the shortfalls would be 26 bn Euros in case of Italy and $12 \mathrm{bn}$ in case of a haircut on Spanish sovereign bonds. But again, this deterioration of the bank capital would have to be borne almost entirely by the domestic banking sector of these countries. ${ }^{12}$

Direct effects on other countries due to the haircuts are almost zero in all three simulations. This is mainly due to an improvement of the capitalization of Greek banks, but also in Germany and France over the year 2013.

${ }_{12}$ Table $5 \mathrm{~A}$ in the appendix shows the results for a haircut on Spanish sovereign bonds. 
Table 9: Effects of a $40 \%$ Haircut on Portuguese Sovereign Bonds: Additional Capital Requirements compared to the unstressed Scenario ${ }^{13}$

EQ3 and EQ4: Thresholds for the ratio of book equity to not-risk weighted total assets of either 3 or $4 \%$. CET1-5.5, CET1-8, CET1-12: Thresholds for the CET1 ratio of 5.5\% (for stress scenarios only), 8\%, and 12\%. In million Euro for the year 2013 .

\begin{tabular}{|l|l|l|l|l|l|}
\hline & EQ3 & EQ4 & CET1-5.5 & CET1-8 & CET1-12 \\
\hline AUSTRIA & 0 & 0 & 0 & 0 & 2 \\
\hline BELGIUM & 0 & 0 & 0 & 0 & 0 \\
\hline CYPRUS & 0 & 0 & 0 & 0 & 0 \\
\hline FINLAND & 0 & 0 & 0 & 0 & 0 \\
\hline FRANCE & 0 & 0 & 0 & 0 & 0 \\
\hline GERMANY & 0 & 257 & 0 & 0 & 62 \\
\hline GREECE & 0 & 0 & 0 & 0 & 0 \\
\hline IRELAND & 0 & 0 & 0 & 0 & 0 \\
\hline ITALY & 0 & 64 & 0 & 0 & 78 \\
\hline LUXEMBOURG & 0 & 0 & 0 & 0 & 0 \\
\hline MALTA & 0 & 0 & 0 & 0 & 1 \\
\hline NETHERLANDS & 0 & 0 & 0 & 0 & 0 \\
\hline PORTUGAL & 637 & 1827 & 0 & 0 & 8610 \\
\hline SLOVENIA & 0 & 0 & 0 & 0 & 0 \\
\hline SPAIN & 0 & 0 & 0 & 0 & 228 \\
\hline
\end{tabular}

${ }_{13}$ The results for the unstressed scenario for these 49 banks are shown in Table $3 \mathrm{~A}$ in the Appendix. 
Table 10: Effects of a 40\% Haircut on Italian Sovereign Bonds: Additional Capital Requirements compared to the unstressed Scenario ${ }^{14}$

EQ3 and EQ4: Thresholds for the ratio of book equity to not-risk weighted total assets of either 3 or $4 \%$. CET1-5.5, CET1-8, CET1-12: Thresholds for the CET1 ratio of 5.5\% (for stress scenarios only), 8\%, and 12\%. In million Euro for the year 2013 .

\begin{tabular}{|l|l|l|l|l|l|}
\hline & EQ3 & EQ4 & CET1-5.5 & CET1-8 & CeT1-12 \\
\hline AUSTRIA & 0 & 0 & 0 & 0 & 100 \\
\hline BELGIUM & 0 & 0 & 0 & 0 & 0 \\
\hline CYPRUS & 0 & 0 & 0 & 0 & 21 \\
\hline FINLAND & 0 & 0 & 0 & 0 & 0 \\
\hline FRANCE & 0 & 0 & 0 & 0 & 392 \\
\hline GERMANY & 129 & 3174 & 0 & 0 & 1550 \\
\hline GREECE & 0 & 0 & 0 & 0 & 45 \\
\hline IRELAND & 0 & 0 & 0 & 0 & 0 \\
\hline ITALY & 11610 & 13013 & 11226 & 26348 & 52233 \\
\hline LUXEMBOURG & 0 & 0 & 0 & 0 & 0 \\
\hline MALTA & 0 & 0 & 0 & 0 & 0 \\
\hline NETHERLANDS & 0 & 266 & 0 & 0 & 0 \\
\hline PORTUGAL & 0 & 19 & 0 & 0 & 4378 \\
\hline SLOVENIA & 0 & 0 & 0 & 0 & 0 \\
\hline SPAIN & 0 & 0 & 0 & 0 & 1153 \\
\hline
\end{tabular}

${ }_{14}$ The results for the unstressed scenario for these 49 banks are shown in Table $3 \mathrm{~A}$ in the Appendix. 


\section{$5 \quad$ Conclusions}

Our results show that the large banks of the Eurozone that are included in the $A Q R$ are better capitalized at the end of 2013 than one year earlier. The capital shortfalls - both with regard to common equity tier 1 and to book equity diminished significantly, particularly in Greece, Spain, Italy, and Germany. This is mainly due to a reduction in total assets and risk-weighted assets in many banks, but also to an improvement in the capital base.

Despite these improvements, capital shortfalls would still occur in our scenarios, even in the status quo scenario. The most significant shortfall would realize in our market downturn scenario. It is a striking feature of our results that capital shortfalls are much larger in the case of book-equity-to-totalasset-ratios. According to Haldane (2012) the simple book-equity-to-assets ratio is much better at predicting failures of banks, in particular large banks, than risk weighted measures like CET1. ${ }^{15}$ Banks seem to be relatively successful in approaching and reaching the official benchmarks set by the supervisors, but additional reserves are not yet built up sufficiently.

Caution is also warranted because we consider stress scenarios in isolation. In a real world crisis situation it is likely that events like a haircut on government debt would probably coincide with a general market downturn, so that capital shortfalls may be much larger than suggested by the isolated scenarios considered here.

Nevertheless the process initiated by the CRD IV directive has been enforced by the announcement of the $A Q R$ and motivated banks to improve their capi-

\footnotetext{
15 The limitations of risk weighting are also emphasized by Admati and Hellwig(2013). Schleer et al. (2014) show in addition that a high leverage of banks leads to more significant restrictions concerning the credit flows to the private sector in crisis periods. 
tal base. Although what has happened so far is not enough, at least the analysis of static balance sheet data performed here suggests that the capital base of the European banking system seems to be moving into the right direction. 


\section{References}

Acharya, Viral V. and Sascha Steffen (2014), Falling short of expectations? Stress-testing the European banking system, CEPS Policy Brief No. 315, 15 January 2014.

Admati, Anat and Martin Hellwig (2013), The Bankers' New Clothes: What's Wrong with Banking and What to Do about It, Princeton: Princeton University Press.

European Banking Association (2014), Main features of the 2014 EU-wide stress test, 31 January 2014.

European Central Bank (2014a), Note on the comprehensive assessment, February 2014.

European Central Bank (2014b), The list of significant supervised entities and the list of less significant institutions, https://www.ecb.europa.eu/ssm/list/html/index.en.html

Haldane, Andrew G. (2012), The dog and the Frisbee, Paper presented at the Federal Reserve Bank of Kansas City's 36th economic policy symposium, “The Changing Policy Landscape", Jackson Hole, Wyoming.

Schleer, Frauke, Willi Semmler, and Julian Illner (2014), Overleveraging in the Banking Sector: Evidence from Europe, ZEW Discussion Paper No. 14-066. 


\section{Appendix}

Table 1A: Basic Financial Statistics for the Banks included in the AQR for the End of the Year 2013

Assets (= total assets) in million Euro; CET1 is the Common Equity Tier 1 ratio (in \%); RWA = ratio of risk-weighted assets relative to total assets (in \%); Equity = ratio of book equity to total assets (in \%). Datasource: Bankscope.

\begin{tabular}{|l|l|r|r|r|r|}
\hline Bank & Country & \multicolumn{1}{c|}{ Assets } & \multicolumn{1}{c|}{ CET1 } & RWA & Equity \\
\hline BAWAG PSK Group & AUSTRIA & 36402 & 15.3 & 43.9 & 7.7 \\
\hline Erste Group Bank AG & AUSTRIA & 199876 & 11.8 & 49.0 & 7.4 \\
\hline $\begin{array}{l}\text { Oesterreichische } \\
\text { Volksbanken AG }\end{array}$ & AUSTRIA & 20904 & 14.1 & 53.9 & 5.8 \\
\hline $\begin{array}{l}\text { Raiffeisen Zentralbank } \\
\text { Oesterreich AG }\end{array}$ & AUSTRIA & 147324 & 10.4 & 60.6 & 8.0 \\
\hline $\begin{array}{l}\text { Raiffeisenlandesbank } \\
\text { Niederoesterreich- } \\
\text { Wien AG }\end{array}$ & AUSTRIA & 29070 & 11.6 & 43.7 & 8.1 \\
\hline $\begin{array}{l}\text { Raiffeisenlandesbank } \\
\text { Oberoesterreich AG }\end{array}$ & AUSTRIA & 37432 & 9.8 & 73.5 & 9.5 \\
\hline $\begin{array}{l}\text { AXA Bank Europe } \\
\text { SA/NV }\end{array}$ & BELGIUM & 36886 & 17.4 & 13.2 & 2.2 \\
\hline $\begin{array}{l}\text { Argenta Spaarbank- } \\
\text { ASPA }\end{array}$ & BELGIUM & 32147 & 17.7 & 22.5 & 4.3 \\
\hline $\begin{array}{l}\text { Bank of New York } \\
\text { Mellon SA/NV }\end{array}$ & BELGIUM & 53982 & 17.3 & 16.8 & 3.5 \\
\hline Belfius Banque SA/NV & BELGIUM & 182777 & 15.4 & 23.3 & 3.6 \\
\hline Dexia & BELGIUM & 222936 & 21.4 & 21.3 & 1.8 \\
\hline $\begin{array}{l}\text { KBC Groep NV/ KBC } \\
\text { Groupe SA }\end{array}$ & BELGIUM & 241306 & 15.8 & 37.5 & 6.0 \\
\hline $\begin{array}{l}\text { Bank of Cyprus Public } \\
\text { Company Ltd }\end{array}$ & CYPRUS & 30342 & 10.2 & 73.7 & 9.0 \\
\hline $\begin{array}{l}\text { Co-operative Central } \\
\text { Bank Limited }\end{array}$ & CYPRUS & 3555 & & 8.4 \\
\hline
\end{tabular}




\begin{tabular}{|l|l|r|r|r|r|}
\hline $\begin{array}{l}\text { Hellenic Bank Public } \\
\text { Company Limited }\end{array}$ & CYPRUS & 6384 & 13.1 & 38.6 & 6.3 \\
\hline RCB Bank Ltd & CYPRUS & 4787 & 26.2 & 6.7 & 1.8 \\
\hline DNB Pank AS & ESTONIA & 567 & & & 17.3 \\
\hline SEB Pank & ESTONIA & 4443 & 21.2 & 74.3 & 17.4 \\
\hline Swedbank As & ESTONIA & 8932 & 32.5 & 63.7 & 21.2 \\
\hline Danske Bank Plc & FINLAND & 26680 & 17.2 & 55.7 & 8.9 \\
\hline $\begin{array}{l}\text { Nordea Bank Finland } \\
\text { Plc }\end{array}$ & FINLAND & 304761 & 15.0 & 18.4 & 3.1 \\
\hline OP-Pohjola Group & FINLAND & 100981 & 14.3 & 40.9 & 7.6 \\
\hline BNP Paribas & FRANCE & 1800139 & 12.8 & 31.2 & 5.1 \\
\hline BPCE Group & FRANCE & 1123520 & 12.8 & 32.9 & 5.2 \\
\hline BPIFrance Financement & FRANCE & 30756 & & & 9.0 \\
\hline $\begin{array}{l}\text { Banque Centrale de } \\
\text { Compensation }\end{array}$ & FRANCE & 254091 & & & 0.1 \\
\hline Banque PSA Finance & FRANCE & 25117 & & & 13.1 \\
\hline $\begin{array}{l}\text { Caisse Francaise de } \\
\text { Financement Local }\end{array}$ & FRANCE & 80017 & & & 1.7 \\
\hline $\begin{array}{l}\text { Caisse de Refinance- } \\
\text { ment de l'Habitat }\end{array}$ & FRANCE & 53134 & & & 0.6 \\
\hline Credit Agricole Group & FRANCE & 1706326 & 13.1 & 30.7 & 4.8 \\
\hline $\begin{array}{l}\text { Credit Mutuel (Combi- } \\
\text { ned - IFRS) }\end{array}$ & FRANCE & 645216 & 14.5 & 30.0 & 6.0 \\
\hline HSBC France & FRANCE & 208893 & 13.7 & 15.5 & 2.6 \\
\hline La Banque Postale & FRANCE & 200232 & 13.2 & 22.6 & 4.3 \\
\hline RCI Banque & FRANCE & 29505 & & & 9.9 \\
\hline Societe Generale & FRANCE & 1235262 & 13.4 & 25.6 & 4.4 \\
\hline Aareal Bank AG & GERMANY & 42981 & 18.5 & 30.6 & 5.7 \\
\hline $\begin{array}{l}\text { Bayerische Landes- } \\
\text { bank }\end{array}$ & GERMANY & 255601 & 15.8 & 34.2 & 5.8 \\
\hline Commerzbank AG & GERMANY & 549661 & 13.5 & 34.6 & 4.9 \\
\hline
\end{tabular}




\begin{tabular}{|c|c|c|c|c|c|}
\hline $\begin{array}{l}\text { DekaBank Deutsche } \\
\text { Girozentrale }\end{array}$ & GERMANY & 116073 & 15.6 & $19 \cdot 3$ & 3.2 \\
\hline $\begin{array}{l}\text { Deutsche Apotheker- } \\
\text { und Aerztebank eG }\end{array}$ & GERMANY & 34692 & 17.0 & 31.4 & 6.3 \\
\hline Deutsche Bank AG & GERMANY & 1611400 & 16.9 & 18.6 & 3.4 \\
\hline $\begin{array}{l}\text { Deutsche Zentral- } \\
\text { Genossenschaftsbank }\end{array}$ & GERMANY & 386978 & 16.4 & 22.0 & 3.7 \\
\hline HASPA Finanzholding & GERMANY & 41611 & 10.6 & 71.1 & $9 \cdot 3$ \\
\hline HSH Nordbank AG & GERMANY & 109022 & $15 \cdot 3$ & 33.6 & 4.1 \\
\hline $\begin{array}{l}\text { Hypo Real Estate Hold- } \\
\text { ing AG }\end{array}$ & GERMANY & 122454 & 32.5 & $14 \cdot 5$ & 5.2 \\
\hline $\begin{array}{l}\text { IKB Deutsche Indust- } \\
\text { riebank AG }\end{array}$ & GERMANY & 24045 & 13.1 & 58.0 & 6.5 \\
\hline KfW Ipex-Bank Gmbh & GERMANY & 23280 & & & 14.9 \\
\hline $\begin{array}{l}\text { Landesbank Baden- } \\
\text { Wuerttemberg }\end{array}$ & GERMANY & 273523 & 18.5 & 29.1 & 4.9 \\
\hline $\begin{array}{l}\text { Landesbank Berlin } \\
\text { Holding AG }\end{array}$ & GERMANY & 102437 & 11.9 & 24.9 & 2.3 \\
\hline $\begin{array}{l}\text { Landesbank Hessen- } \\
\text { Thueringen - HELABA }\end{array}$ & GERMANY & 178083 & 12.8 & 30.9 & 4.0 \\
\hline $\begin{array}{l}\text { Landeskreditbank Ba- } \\
\text { den-Wuerttemberg }\end{array}$ & GERMANY & 70141 & 15.7 & $25 \cdot 5$ & $4 \cdot 3$ \\
\hline $\begin{array}{l}\text { Landwirtschaftliche } \\
\text { Rentenbank }\end{array}$ & GERMANY & 81932 & 23.9 & 16.5 & 3.9 \\
\hline $\begin{array}{l}\text { Muenchener Hypothe- } \\
\text { kenbank eG }\end{array}$ & GERMANY & 34717 & 11.7 & 21.2 & 2.6 \\
\hline NRWBANK & GERMANY & 143153 & 44.0 & 27.1 & 12.9 \\
\hline $\begin{array}{l}\text { Norddeutsche Landes- } \\
\text { bank }\end{array}$ & GERMANY & 200845 & 11.8 & 34.1 & 4.1 \\
\hline SEB AG & GERMANY & 31754 & 13.6 & 37.2 & 6.5 \\
\hline $\begin{array}{l}\text { Volkswagen Financial } \\
\text { Services AG }\end{array}$ & GERMANY & 90992 & 8.6 & 91.2 & 9.8 \\
\hline WGZ-Bank AG & GERMANY & 90926 & & & 3.6 \\
\hline
\end{tabular}




\begin{tabular}{|c|c|c|c|c|c|}
\hline $\begin{array}{l}\text { Wuestenrot und Wuert- } \\
\text { tembergische }\end{array}$ & GERMANY & 75043 & & & $4 \cdot 3$ \\
\hline Alpha Bank AE & GREECE & 73697 & & & 11.4 \\
\hline Eurobank Ergasias SA & GREECE & 77586 & 11.5 & 47.7 & 5.8 \\
\hline $\begin{array}{l}\text { National Bank of } \\
\text { Greece SA }\end{array}$ & GREECE & 110930 & 10.3 & 50.1 & 7.1 \\
\hline Piraeus Bank SA & GREECE & 85778 & 15.2 & 61.3 & 9.6 \\
\hline Allied Irish Banks plc & IRELAND & 117734 & $14 \cdot 3$ & 53.0 & 8.9 \\
\hline $\begin{array}{l}\text { Bank of Ireland- } \\
\text { Governor and Compa- } \\
\text { ny }\end{array}$ & IRELAND & 132137 & 12.4 & 42.7 & 6.0 \\
\hline $\begin{array}{l}\text { Merrill Lynch Interna- } \\
\text { tional Bank Ltd }\end{array}$ & IRELAND & 294444 & & & 2.0 \\
\hline Permanent TSB Plc & IRELAND & 37604 & 13.6 & 43.4 & 6.3 \\
\hline $\begin{array}{l}\text { Ulster Bank Ireland } \\
\text { Limited }\end{array}$ & IRELAND & 35375 & 11.5 & 110.0 & 13.1 \\
\hline Banca Carige SpA & ITALY & 42156 & 5.8 & 51.4 & 3.9 \\
\hline $\begin{array}{l}\text { Banca Monte dei Pa- } \\
\text { schi di Siena SpA }\end{array}$ & ITALY & 199106 & 10.6 & 42.4 & 3.1 \\
\hline $\begin{array}{l}\text { Banca Popolare di Mi- } \\
\text { lano SCaRL }\end{array}$ & ITALY & 49353 & 7.8 & 86.4 & 7.4 \\
\hline $\begin{array}{l}\text { Banca Popolare di } \\
\text { Sondrio }\end{array}$ & ITALY & 32770 & 7.9 & 72.5 & 6.1 \\
\hline $\begin{array}{l}\text { Banca Popolare di } \\
\text { Vicenza }\end{array}$ & ITALY & 45235 & 9.2 & 62.1 & 8.1 \\
\hline $\begin{array}{l}\text { Banca popolare } \\
\text { dell'Emilia Romagna }\end{array}$ & ITALY & 61758 & 8.6 & 69.6 & 7.6 \\
\hline $\begin{array}{l}\text { Banco Popolare - } \\
\text { Societa Cooperativa }\end{array}$ & ITALY & 126043 & 10.6 & 39.1 & 6.8 \\
\hline $\begin{array}{l}\text { Credito Emiliano SpA- } \\
\text { CREDEM }\end{array}$ & ITALY & 31531 & 9.9 & 52.4 & 6.8 \\
\hline $\begin{array}{l}\text { Credito Valtellinese } \\
\text { Soc Coop }\end{array}$ & ITALY & 27199 & 8.6 & 64.3 & 7.0 \\
\hline
\end{tabular}




\begin{tabular}{|c|c|c|c|c|c|}
\hline Iccrea Holding SpA & ITALY & 40045 & 9.3 & 35.2 & 3.7 \\
\hline Intesa Sanpaolo & ITALY & 626283 & 12.2 & $44 \cdot 3$ & 7.2 \\
\hline Mediobanca SpA & ITALY & 72841 & 11.7 & 71.9 & $9 \cdot 5$ \\
\hline UniCredit SpA & ITALY & 845838 & 10.1 & 50.1 & 5.9 \\
\hline $\begin{array}{l}\text { Unione di Banche Itali- } \\
\text { ane Scpa-UBI }\end{array}$ & ITALY & 124242 & 13.2 & 49.1 & 9.0 \\
\hline Veneto Banca scpa & ITALY & 37307 & 7.7 & 66.8 & 8.5 \\
\hline ABLV Bank AS & LATVIA & 3281 & & & 5.7 \\
\hline SEB banka AS & LATVIA & 4226 & & & 10.2 \\
\hline Swedbank AS & LATVIA & 5000 & 28.0 & 62.5 & 20.2 \\
\hline $\begin{array}{l}\text { Banque Internationale } \\
\text { a Luxembourg SA }\end{array}$ & LUXEMBOURG & 19699 & 14.9 & 22.1 & 5.9 \\
\hline $\begin{array}{l}\text { Banque et Caisse d'E- } \\
\text { pargne de l'Etat Lu- } \\
\text { xembourg }\end{array}$ & LUXEMBOURG & 40714 & 16.6 & 30.6 & 9.1 \\
\hline $\begin{array}{l}\text { Clearstream Banking } \\
\text { SA }\end{array}$ & LUXEMBOURG & 11247 & & & 6.0 \\
\hline $\begin{array}{l}\text { KBL European Private } \\
\text { Bankers SA }\end{array}$ & LUXEMBOURG & 12469 & $13 \cdot 5$ & 31.0 & $7 \cdot 7$ \\
\hline $\begin{array}{l}\text { RBC Investor Services } \\
\text { Bank SA }\end{array}$ & LUXEMBOURG & 12574 & & & $7 \cdot 3$ \\
\hline $\begin{array}{l}\text { State Street Bank Lux- } \\
\text { embourg SA }\end{array}$ & LUXEMBOURG & 8742 & & & 32.9 \\
\hline UBS (Luxembourg) SA & LUXEMBOURG & 9302 & & & 6.5 \\
\hline Bank of Valletta Plc & MALTA & 7258 & 11.7 & 49.4 & $7 \cdot 9$ \\
\hline HSBC Bank Malta Plc & MALTA & 5722 & 9.4 & $49 \cdot 3$ & 7.4 \\
\hline ABN AMRO Group NV & NETHERLANDS & 372022 & $15 \cdot 3$ & 29.3 & 3.6 \\
\hline $\begin{array}{l}\text { Bank Nederlandse } \\
\text { Gemeenten NV. BNG }\end{array}$ & NETHERLANDS & 131183 & 24.0 & 8.9 & 2.6 \\
\hline ING Bank NV & NETHERLANDS & 787644 & 13.5 & $35 \cdot 9$ & $4 \cdot 3$ \\
\hline $\begin{array}{l}\text { Nederlandse Water- } \\
\text { schapsbank NV }\end{array}$ & NETHERLANDS & 73006 & & & 1.7 \\
\hline
\end{tabular}




\begin{tabular}{|c|c|c|c|c|c|}
\hline $\begin{array}{l}\text { Rabobank Nederland- } \\
\text { Rabobank Group }\end{array}$ & NETHERLANDS & 674139 & 16.6 & 31.4 & 5.9 \\
\hline $\begin{array}{l}\text { Royal Bank of Scotland } \\
\text { NV }\end{array}$ & NETHERLANDS & 39385 & & & 7.5 \\
\hline SNS Bank NV & NETHERLANDS & 74537 & 16.6 & 19.5 & 3.5 \\
\hline Banco BPI SA & PORTUGAL & 42700 & 16.2 & 51.0 & 5.4 \\
\hline $\begin{array}{l}\text { Banco Comercial Por- } \\
\text { tugues }\end{array}$ & PORTUGAL & 82007 & 12.9 & 53.4 & 4.0 \\
\hline $\begin{array}{l}\text { Caixa Geral de Deposi- } \\
\text { tos }\end{array}$ & PORTUGAL & 112963 & 11.3 & $54 \cdot 9$ & 6.0 \\
\hline $\begin{array}{l}\text { Espirito Santo Finan- } \\
\text { cial Group SA }\end{array}$ & PORTUGAL & 84850 & 9.2 & 70.3 & 7.9 \\
\hline $\begin{array}{l}\text { Slovenska sporitel'na } \\
\text { as-Slovak Savings } \\
\text { Bank }\end{array}$ & SLOVAKIA & 11699 & 20.8 & 40.0 & 11.0 \\
\hline Tatra Banka as & SLOVAKIA & 9469 & & & 10.7 \\
\hline $\begin{array}{l}\text { Vseobecna Uverova } \\
\text { Banka as }\end{array}$ & SLOVAKIA & 11556 & 15.9 & 59.0 & 11.9 \\
\hline $\begin{array}{l}\text { NLB dd-Nova Ljubl- } \\
\text { janska Banka dd }\end{array}$ & SLOVENIA & 12490 & 14.9 & $64 \cdot 5$ & 10.2 \\
\hline $\begin{array}{l}\text { Nova Kreditna Banka } \\
\text { Maribor dd }\end{array}$ & SLOVENIA & 4811 & 18.1 & 59.8 & 11.6 \\
\hline $\begin{array}{l}\text { SID - Slovene Export } \\
\text { and Development Bank }\end{array}$ & SLOVENIA & 3940 & & & 9.5 \\
\hline $\begin{array}{l}\text { Banco Bilbao Vizcaya } \\
\text { Argentaria SA }\end{array}$ & SPAIN & 582575 & 12.2 & 55.7 & 7.7 \\
\hline $\begin{array}{l}\text { Banco Financiero y de } \\
\text { Ahorros SA }\end{array}$ & SPAIN & 269159 & 11.8 & 35.1 & 4.6 \\
\hline $\begin{array}{l}\text { Banco Mare Nostrum } \\
\text { SA-BMN }\end{array}$ & SPAIN & 47519 & 10.3 & 39.3 & 4.4 \\
\hline $\begin{array}{l}\text { Banco Popular Espanol } \\
\text { SA }\end{array}$ & SPAIN & 147852 & 12.0 & 54.5 & 7.9 \\
\hline Banco Santander SA & SPAIN & 1115638 & 12.6 & 43.9 & 7.2 \\
\hline Banco de Sabadell SA & SPAIN & 163442 & 12.0 & 44.4 & 6.4 \\
\hline
\end{tabular}




\begin{tabular}{|l|l|r|r|r|r|}
\hline Bankinter SA & SPAIN & 55136 & 12.9 & 41.3 & 6.2 \\
\hline $\begin{array}{l}\text { CAJAMAR Sociedad } \\
\text { Cooperativa de Credito }\end{array}$ & SPAIN & 42105 & & & 6.6 \\
\hline $\begin{array}{l}\text { Caja Espana de Inver- } \\
\text { siones Salamanca }\end{array}$ & SPAIN & 35527 & & & 1.8 \\
\hline Catalunya Banc SA & SPAIN & 63062 & 14.3 & 28.7 & 4.0 \\
\hline Ibercaja Banco SAU & SPAIN & 63118 & 10.3 & 38.1 & 4.1 \\
\hline Kutxabank SA & SPAIN & 60762 & 12.0 & 60.1 & 8.1 \\
\hline LA CAIXA & SPAIN & 351269 & 12.7 & 39.7 & 7.8 \\
\hline Liberbank SA & SPAIN & 44547 & 10.4 & 38.4 & 3.6 \\
\hline NCG Banco SA & SPAIN & 52687 & 11.3 & 44.1 & 5.2 \\
\hline Unicaja & SPAIN & 41243 & & & 5.1 \\
\hline
\end{tabular}

Table 2A: Basic Financial Statistics for the Banks included in the AQR for the End of the Year 2012

Assets (= total assets) in million Euro; CET1 is the Common Equity Tier 1 ratio (in \%); RWA = ratio of risk-weighted assets relative to total assets (in \%); Equity = ratio of book equity to total assets (in \%). Datasource: Bankscope.

\begin{tabular}{|l|l|r|r|r|r|}
\hline Bank & Country & Assets & CET1 & RWA & Equity \\
\hline BAWAG PSK Group & AUSTRIA & 41265 & 11.7 & 50.0 & 6.9 \\
\hline Erste Group Bank AG & AUSTRIA & 213824 & 11.6 & 49.3 & 8.2 \\
\hline $\begin{array}{l}\text { Oesterreichische } \\
\text { Volksbanken AG }\end{array}$ & AUSTRIA & 27667 & 10.9 & 56.8 & 4.3 \\
\hline $\begin{array}{l}\text { Raiffeisen Zentralbank } \\
\text { Oesterreich AG }\end{array}$ & AUSTRIA & 145955 & 13.9 & 49.5 & 8.3 \\
\hline $\begin{array}{l}\text { Raiffeisenlandesbank } \\
\text { Niederoesterreich- } \\
\text { Wien AG }\end{array}$ & AUSTRIA & & & & \\
\hline $\begin{array}{l}\text { Raiffeisenlandesbank } \\
\text { Oberoesterreich AG }\end{array}$ & AUSTRIA & 32310 & 10.3 & 44.0 & 7.5 \\
\hline AXA Bank Europe & BELGIUM & 39217 & 16.5 & 12.5 & 2.1 \\
\hline
\end{tabular}




\begin{tabular}{|l|l|r|r|r|r|}
\hline SA/NV & & & & & \\
\hline $\begin{array}{l}\text { Argenta Spaarbank- } \\
\text { ASPA }\end{array}$ & BELGIUM & 34145 & & & 3.8 \\
\hline $\begin{array}{l}\text { Bank of New York } \\
\text { Mellon SA/NV }\end{array}$ & BELGIUM & 53982 & 17.3 & 16.8 & 3.5 \\
\hline Belfius Banque SA/NV & BELGIUM & 212947 & 13.3 & 23.6 & 2.5 \\
\hline Dexia & BELGIUM & 357210 & 19.9 & 15.5 & 0.9 \\
\hline $\begin{array}{l}\text { KBC Groep NV/ KBC } \\
\text { Groupe SA }\end{array}$ & BELGIUM & 256886 & 13.8 & 39.8 & 6.2 \\
\hline $\begin{array}{l}\text { Bank of Cyprus Public } \\
\text { Company Ltd }\end{array}$ & CYPRUS & 31032 & 0.6 & 69.5 & 1.1 \\
\hline $\begin{array}{l}\text { Co-operative Central } \\
\text { Bank Limited }\end{array}$ & CYPRUS & & & & \\
\hline $\begin{array}{l}\text { Hellenic Bank Public } \\
\text { Company Limited }\end{array}$ & CYPRUS & 8756 & 8.2 & 60.7 & 5.5 \\
\hline RCB Bank Ltd & CYPRUS & & & & \\
\hline DNB Pank AS & ESTONIA & 485 & & & 19.4 \\
\hline SEB Pank & ESTONIA & 4183 & 23.1 & 72.4 & 16.8 \\
\hline Swedbank As & ESTONIA & 8961 & & & 20.4 \\
\hline Danske Bank Plc & FINLAND & 31813 & 15.8 & 51.3 & 7.5 \\
\hline $\begin{array}{l}\text { Nordea Bank Finland } \\
\text { Plc }\end{array}$ & FINLAND & 341947 & 18.0 & 13.4 & 2.7 \\
\hline OP-Pohjola Group & FINLAND & 99769 & 14.0 & 38.2 & 7.2 \\
\hline BNP Paribas & FRANCE & 1907290 & 13.6 & 28.9 & 5.0 \\
\hline BPCE Group & FRANCE & 1147521 & 12.2 & 33.2 & 4.7 \\
\hline BPIFrance Financement & FRANCE & 29941 & 10.5 & 83.1 & 16.2 \\
\hline $\begin{array}{l}\text { Banque Centrale de } \\
\text { Compensation }\end{array}$ & FRANCE & & & 0.1 \\
\hline Banque PSA Finance & FRANCE & & & & 0.6 \\
\hline $\begin{array}{l}\text { Caisse Francaise de } \\
\text { Financement Local }\end{array}$ & FRANCE & & & & 12.6 \\
\hline Caisse de Refinance- & FRANCE & & & \\
\hline
\end{tabular}

40 


\begin{tabular}{|l|l|r|r|r|r|}
\hline ment de l'Habitat & & & & & \\
\hline Credit Agricole Group & FRANCE & 2008152 & 13.3 & 23.9 & 3.8 \\
\hline $\begin{array}{l}\text { Credit Mutuel (Combi- } \\
\text { ned - IFRS) }\end{array}$ & FRANCE & 645216 & 14.5 & 30.0 & 6.0 \\
\hline HSBC France & FRANCE & 225208 & 13.6 & 13.5 & 2.3 \\
\hline La Banque Postale & FRANCE & 195787 & 12.1 & 20.0 & 3.6 \\
\hline RCI Banque & FRANCE & 28767 & & & 9.3 \\
\hline Societe Generale & FRANCE & 1250696 & 12.5 & 25.9 & 4.3 \\
\hline Aareal Bank AG & GERMANY & 45734 & 16.7 & 31.7 & 5.1 \\
\hline $\begin{array}{l}\text { Bayerische Landes- } \\
\text { bank }\end{array}$ & GERMANY & 286823 & 12.9 & 35.0 & 5.3 \\
\hline Commerzbank AG & GERMANY & 635878 & 13.1 & 32.7 & 4.3 \\
\hline $\begin{array}{l}\text { DekaBank Deutsche } \\
\text { Girozentrale }\end{array}$ & GERMANY & 129744 & 14.0 & 18.2 & 2.8 \\
\hline $\begin{array}{l}\text { Deutsche Apotheker- } \\
\text { und Aerztebank eG }\end{array}$ & GERMANY & 37886 & & & \\
\hline Deutsche Bank AG & GERMANY & 2012329 & 15.1 & 16.6 & 2.7 \\
\hline $\begin{array}{l}\text { Deutsche Zentral- } \\
\text { Genossenschaftsbank }\end{array}$ & GERMANY & 199301 & 11.4 & 30.5 & 3.4 \\
\hline HASPA Finanzholding & GERMANY & 41611 & & & \\
\hline HSH Nordbank AG & GERMANY & 130606 & 11.5 & 46.7 & 4.0 \\
\hline $\begin{array}{l}\text { Hypo Real Estate Hold- } \\
\text { ing AG }\end{array}$ & GERMANY & 168977 & 31.3 & 10.8 & 3.7 \\
\hline $\begin{array}{l}\text { IKB Deutsche Indust- } \\
\text { riebank AG }\end{array}$ & GERMANY & 26923 & 9.8 & 58.5 & 4.2 \\
\hline KfW Ipex-Bank Gmbh & GERMANY & 23365 & & & 14.6 \\
\hline $\begin{array}{l}\text { Landesbank Baden- } \\
\text { Wuerttemberg }\end{array}$ & GERMANY & & & & \\
\hline $\begin{array}{l}\text { Landesbank Berlin } \\
\text { Holding AG }\end{array}$ & GERMANY & 136326 & 15.3 & 28.5 & 3.1 \\
\hline $\begin{array}{l}\text { Landesbank Hessen- } \\
\text { Thueringen - HELABA }\end{array}$ & GERMANY & & & \\
\hline
\end{tabular}




\begin{tabular}{|c|c|c|c|c|c|}
\hline $\begin{array}{l}\text { Landeskreditbank Ba- } \\
\text { den-Wuerttemberg }\end{array}$ & GERMANY & 70096 & & & 4.1 \\
\hline $\begin{array}{l}\text { Landwirtschaftliche } \\
\text { Rentenbank }\end{array}$ & GERMANY & 88398 & & & 2.9 \\
\hline $\begin{array}{l}\text { Muenchener Hypothe- } \\
\text { kenbank eG }\end{array}$ & GERMANY & 36643 & & & 2.2 \\
\hline NRWBANK & GERMANY & 146828 & & 23.2 & 12.5 \\
\hline $\begin{array}{l}\text { Norddeutsche Landes- } \\
\text { bank }\end{array}$ & GERMANY & 225550 & 10.9 & 34.5 & 3.4 \\
\hline SEB AG & GERMANY & 35634 & 12.2 & 35.6 & 5.8 \\
\hline $\begin{array}{l}\text { Volkswagen Financial } \\
\text { Services AG }\end{array}$ & GERMANY & 87379 & 9.2 & 87.2 & 10.1 \\
\hline WGZ-Bank AG & GERMANY & 96082 & & & 3.2 \\
\hline $\begin{array}{l}\text { Wuestenrot und Wuert- } \\
\text { tembergische }\end{array}$ & GERMANY & 77193 & & & 4.4 \\
\hline Alpha Bank AE & GREECE & 58357 & & & 1.3 \\
\hline Eurobank Ergasias SA & GREECE & 67653 & 116.4 & 5.6 & -1.0 \\
\hline $\begin{array}{l}\text { National Bank of } \\
\text { Greece SA }\end{array}$ & GREECE & 104799 & -6.7 & 61.6 & -1.8 \\
\hline Piraeus Bank SA & GREECE & 63020 & 10.3 & 56.7 & $-4 \cdot 3$ \\
\hline Allied Irish Banks plc & IRELAND & 122516 & 15.1 & 58.3 & 9.2 \\
\hline $\begin{array}{l}\text { Bank of Ireland- } \\
\text { Governor and Compa- } \\
\text { ny }\end{array}$ & IRELAND & 148146 & $14 \cdot 5$ & 38.1 & 5.8 \\
\hline $\begin{array}{l}\text { Merrill Lynch Interna- } \\
\text { tional Bank Ltd }\end{array}$ & IRELAND & 371741 & & & 1.8 \\
\hline Permanent TSB Plc & IRELAND & 40919 & 18.4 & 36.3 & 6.9 \\
\hline $\begin{array}{l}\text { Ulster Bank Ireland } \\
\text { Limited }\end{array}$ & IRELAND & 40912 & 11.4 & 110.7 & 20.2 \\
\hline Banca Carige SpA & ITALY & 49326 & 7.4 & 49.4 & 7.5 \\
\hline $\begin{array}{l}\text { Banca Monte dei Pa- } \\
\text { schi di Siena SpA }\end{array}$ & ITALY & 218882 & 9.6 & 42.4 & 2.9 \\
\hline Banca Popolare di Mi- & ITALY & 52475 & 9.0 & 82.3 & 7.7 \\
\hline
\end{tabular}

42 


\begin{tabular}{|l|l|r|r|r|r|}
\hline lano SCaRL & & & & & \\
\hline $\begin{array}{l}\text { Banca Popolare di } \\
\text { Sondrio }\end{array}$ & ITALY & 32349 & 7.6 & 75.0 & 6.0 \\
\hline $\begin{array}{l}\text { Banca Popolare di } \\
\text { Vicenza }\end{array}$ & ITALY & 46709 & 8.2 & 61.8 & 7.2 \\
\hline $\begin{array}{l}\text { Banca popolare } \\
\text { dell'Emilia Romagna }\end{array}$ & ITALY & 61638 & 8.3 & 72.6 & 7.7 \\
\hline $\begin{array}{l}\text { Banco Popolare - } \\
\text { Societa Cooperativa }\end{array}$ & ITALY & 131921 & 11.2 & 41.8 & 6.8 \\
\hline $\begin{array}{l}\text { Credito Emiliano SpA- } \\
\text { CREDEM }\end{array}$ & ITALY & 30749 & 9.4 & 54.3 & 6.5 \\
\hline $\begin{array}{l}\text { Credito Valtellinese } \\
\text { Soc Coop }\end{array}$ & ITALY & 29896 & 8.1 & 66.5 & 6.6 \\
\hline Iccrea Holding SpA & ITALY & 40045 & 9.3 & 35.2 & 3.7 \\
\hline Intesa Sanpaolo & ITALY & 673472 & 12.1 & 44.3 & 7.5 \\
\hline Mediobanca SpA & ITALY & 78679 & 11.5 & 70.1 & 8.4 \\
\hline UniCredit SpA & ITALY & 926828 & 11.4 & 46.1 & 7.2 \\
\hline $\begin{array}{l}\text { Unione di Banche Itali- } \\
\text { ane Scpa-UBI }\end{array}$ & ITALY & 132434 & 10.8 & 57.8 & 8.0 \\
\hline Veneto Banca Scpa & ITALY & 40165 & 7.9 & 63.3 & 7.7 \\
\hline ABLV Bank AS & LATVIA & 3039 & & & 4.9 \\
\hline SEB banka AS & LATVIA & 3955 & & & 11.0 \\
\hline Swedbank AS & LATVIA & 4912 & 21.7 & 75.1 & 18.5 \\
\hline $\begin{array}{l}\text { Banque Internationale } \\
\text { a Luxembourg SA }\end{array}$ & LUXEMBOURG & 14.4 & 19.8 & 5.2 \\
\hline $\begin{array}{l}\text { Banque et Caisse d'E- } \\
\text { pargne de I'Etat Lu- } \\
\text { xembourg }\end{array}$ & LUXEMBOURG & & 12937 & 32.2 & 7.2 \\
\hline $\begin{array}{l}\text { Clearstream Banking } \\
\text { SA }\end{array}$ & LUXEMBOURG & & & 7.0 \\
\hline $\begin{array}{l}\text { KBL European Private } \\
\text { Bankers SA }\end{array}$ & LUXEMBOURG & & & 8.4 \\
\hline RBC Investor Services & LUXEMBOURG & & & \\
\hline
\end{tabular}




\begin{tabular}{|l|l|r|r|r|r|}
\hline Bank SA & & & & \\
\hline $\begin{array}{l}\text { State Street Bank Lux- } \\
\text { embourg SA }\end{array}$ & LUXEMBOURG & 7541 & & & 35.5 \\
\hline UBS (Luxembourg) SA & LUXEMBOURG & 9302 & & & 6.5 \\
\hline Bank of Valletta PIC & MALTA & 7049 & 10.7 & 51.3 & 7.4 \\
\hline HSBC Bank Malta Plc & MALTA & 5886 & 8.3 & 48.1 & 6.8 \\
\hline ABN AMRO Group NV & NETHERLANDS & 394404 & 12.9 & 30.8 & 3.6 \\
\hline $\begin{array}{l}\text { Bank Nederlandse } \\
\text { Gemeenten NV. BNG }\end{array}$ & NETHERLANDS & 142228 & 22.0 & 8.2 & 1.9 \\
\hline ING Bank NV & NETHERLANDS & 836068 & 14.3 & 33.3 & 4.5 \\
\hline $\begin{array}{l}\text { Nederlandse Water- } \\
\text { schapsbank NV }\end{array}$ & NETHERLANDS & 76084 & & 1.4 & 1.6 \\
\hline $\begin{array}{l}\text { Rabobank Nederland- } \\
\text { Rabobank Group }\end{array}$ & NETHERLANDS & 752410 & 17.2 & 29.6 & 5.9 \\
\hline $\begin{array}{l}\text { Royal Bank of Scotland } \\
\text { NV }\end{array}$ & NETHERLANDS & 71401 & & & \\
\hline SNS Bank NV & NETHERLANDS & 81341 & 7.7 & 25.3 & 1.6 \\
\hline Banco BPI SA & PORTUGAL & 44565 & 15.2 & 55.0 & 4.6 \\
\hline $\begin{array}{l}\text { Banco Comercial Por- } \\
\text { tugues }\end{array}$ & PORTUGAL & 89744 & 12.4 & 59.4 & 4.5 \\
\hline $\begin{array}{l}\text { Caixa Geral de Deposi- } \\
\text { tos }\end{array}$ & PORTUGAL & 116857 & 11.2 & 58.5 & 6.2 \\
\hline $\begin{array}{l}\text { Espirito Santo Finan- } \\
\text { cial Group SA }\end{array}$ & PORTUGAL & 11773 & 16.2 & 45.8 & 10.2 \\
\hline $\begin{array}{l}\text { Slovenska sporitel'na } \\
\text { as-Slovak Savings } \\
\text { Bank }\end{array}$ & SLOVAKIA & 9.1 & 74.3 & 9.3 \\
\hline Tatra Banka as & SLOVAKIA & 8.1 & 81.2 & 4.8 \\
\hline $\begin{array}{l}\text { Vseobecna Uverova } \\
\text { Banka as }\end{array}$ & SLOVAKIA & 17.1 & 61.8 & 11.7 \\
\hline $\begin{array}{l}\text { NLB dd-Nova Ljubl- } \\
\text { janska Banka dd }\end{array}$ & SLOVENIA & & 62.5 & 11.8 \\
\hline Nova Kreditna Banka & SLOVENIA & & & 8.0 \\
\hline
\end{tabular}




\begin{tabular}{|c|c|c|c|c|c|}
\hline Maribor dd & & & & & \\
\hline $\begin{array}{l}\text { SID - Slovene Export } \\
\text { and Development } \\
\text { Bank }\end{array}$ & SLOVENIA & 4258.8 & & & 8.5 \\
\hline $\begin{array}{l}\text { Banco Bilbao Vizcaya } \\
\text { Argentaria SA }\end{array}$ & SPAIN & 637785 & 10.8 & 51.6 & 6.9 \\
\hline $\begin{array}{l}\text { Banco Financiero y de } \\
\text { Ahorros SA }\end{array}$ & SPAIN & 309187 & 5.2 & 36.2 & 1.0 \\
\hline $\begin{array}{l}\text { Banco Mare Nostrum } \\
\text { SA-BMN }\end{array}$ & SPAIN & 63380 & & 42.1 & 0.3 \\
\hline $\begin{array}{l}\text { Banco Popular Espanol } \\
\text { SA }\end{array}$ & SPAIN & 157618 & 10.3 & 56.3 & 6.3 \\
\hline Banco Santander SA & SPAIN & 1269628 & 11.2 & 43.9 & 6.6 \\
\hline Banco de Sabadell SA & SPAIN & 161547 & 10.6 & 45.8 & $5 \cdot 7$ \\
\hline Bankinter SA & SPAIN & 58166 & 10.8 & 43.7 & 5.6 \\
\hline $\begin{array}{l}\text { CAJAMAR Sociedad } \\
\text { Cooperativa de Credito }\end{array}$ & SPAIN & 43097 & & 57.1 & 5.8 \\
\hline $\begin{array}{l}\text { Caja Espana de Inver- } \\
\text { siones Salamanca }\end{array}$ & SPAIN & 37891 & & & -2.8 \\
\hline Catalunya Banc SA & SPAIN & 74104 & & & 0.8 \\
\hline Ibercaja Banco SAU & SPAIN & 44664 & 10.4 & 43.4 & 4.8 \\
\hline Kutxabank SA & SPAIN & 66707 & 10.1 & 63.6 & 7.2 \\
\hline LA CAIXA & SPAIN & 359109 & 10.4 & 47.8 & 6.9 \\
\hline Liberbank SA & SPAIN & 46255 & 5.2 & 44.8 & 2.4 \\
\hline NCG Banco SA & SPAIN & 59983 & 6.9 & 47.8 & 2.2 \\
\hline Unicaja & SPAIN & 40714 & 11.2 & 44.4 & 5.0 \\
\hline
\end{tabular}


Table 3A: The 49 Banks included in the Analysis of disaggregated Sovereign Bond Holdings (described in Section 4.4 of this Study)

\begin{tabular}{|l|l|}
\hline BANK & COUNTRY \\
\hline Erste Group Bank AG & AUSTRIA \\
\hline Raiffeisen Zentralbank Oesterreich AG & AUSTRIA \\
\hline KBC Groep NV/ KBC Groupe SA & BELGIUM \\
\hline Bank of Cyprus Public Company Ltd & CYPRUS \\
\hline OP-Pohjola Group & FINLAND \\
\hline BNP Paribas & FRANCE \\
\hline BPCE Group & FRANCE \\
\hline Credit Agricole Group & FRANCE \\
\hline Societe Generale & FRANCE \\
\hline Bayerische Landesbank & GERMANY \\
\hline Commerzbank AG & GERMANY \\
\hline DekaBank Deutsche Girozentrale & GERMANY \\
\hline Deutsche Bank AG & GERMANY \\
\hline Deutsche Zentral-Genossenschaftsbank & GERMANY \\
\hline HSH Nordbank AG & GERMANY \\
\hline Hypo Real Estate Holding AG & GERMANY \\
\hline Landesbank Baden-Wuerttemberg & GERMANY \\
\hline Landesbank Berlin Holding AG & GERMANY \\
\hline Landesbank Hessen-Thueringen - HELABA & GERMANY \\
\hline Norddeutsche Landesbank & GERMANY \\
\hline WGZ-Bank AG & GERMANY \\
\hline Alpha Bank AE & GREECE \\
\hline Eurobank Ergasias SA & GREECE \\
\hline National Bank of Greece SA & GREECE \\
\hline Piraeus Bank SA & GREECE \\
\hline Allied Irish Banks plc & IRELAND \\
\hline
\end{tabular}

46 


\begin{tabular}{|l|l|}
\hline Bank of Ireland-Governor and Company & IRELAND \\
\hline Permanent TSB Plc & IRELAND \\
\hline Banca Monte dei Paschi di Siena SpA & ITALY \\
\hline Banco Popolare - Societa Cooperativa & ITALY \\
\hline Intesa Sanpaolo & ITALY \\
\hline UniCredit SpA & ITALY \\
\hline Unione di Banche Italiane Scpa-UBI & ITALY \\
\hline Banque et Caisse d'Epargne de l'Etat Luxem- \\
bourg & LUXEMBOURG \\
\hline Bank of Valletta Plc & MALTA \\
\hline ABN AMRO Group NV & NETHERLANDS \\
\hline ING Bank NV & NETHERLANDS \\
\hline Rabobank Nederland-Rabobank Group & NETHERLANDS \\
\hline SNS Bank NV & NETHERLANDS \\
\hline Banco BPI SA & PORTUGAL \\
\hline Banco Comercial Portugues & PORTUGAL \\
\hline Caixa Geral de Depositos & PORTUGAL \\
\hline Espirito Santo Financial Group SA & PORTUGAL \\
\hline NLB dd-Nova Ljubljanska Banka dd & SLOVENIA \\
\hline Nova Kreditna Banka Maribor dd & SLOVENIA \\
\hline Banco Bilbao Vizcaya Argentaria SA & SPAIN \\
\hline Banco Popular Espanol SA & SPAIN \\
\hline Banco Santander SA & SPAIN \\
\hline LA CAIXA & SPAIN \\
\hline
\end{tabular}


Table 4A: Results for the Status quo Scenario for the largest 49 Banks in the Eurozone (see Section 4.4 of this Study)

EQ3 and EQ4: Thresholds for the ratio of book equity to (not-risk weighted) total assets of either $3 \%$ or $4 \%$. CET1-5.5, CET1-8, CET1-12: Thresholds for the common equity tier 1 ratio of $5.5 \%$ (for stress scenarios only), $8 \%$, and $12 \%$. In million Euro.

\begin{tabular}{|l|l|l|l|l|l|}
\hline & EQ3 & EQ4 & CET1-5.5 & CET1-8 & CET1-12 \\
\hline AUSTRIA & 0 & 0 & 0 & 0 & 1625 \\
\hline BELGIUM & 0 & 0 & 0 & 0 & 0 \\
\hline CYPRUS & 0 & 0 & 0 & 0 & 402 \\
\hline FINLAND & 0 & 0 & 0 & 0 & 0 \\
\hline FRANCE & 0 & 0 & 0 & 0 & 0 \\
\hline GERMANY & 732 & 13847 & 0 & 0 & 143 \\
\hline GREECE & 0 & 0 & 0 & 0 & 1130 \\
\hline IRELAND & 0 & 0 & 0 & 0 & 0 \\
\hline ITALY & 0 & 1800 & 0 & 0 & 9947 \\
\hline LUXEMBOURG & 0 & 0 & 0 & 0 & 0 \\
\hline MALTA & 0 & 0 & 0 & 0 & 11 \\
\hline NETHERLANDS & 0 & 1712 & 0 & 0 & 0 \\
\hline PORTUGAL & 0 & 4 & 0 & 0 & 1669 \\
\hline SLOVENIA & 0 & 0 & 0 & 0 & 0 \\
\hline SPAIN & 0 & 0 & 0 & 0 & 16 \\
\hline
\end{tabular}


Table 5A: Effects of a $40 \%$ Haircut on Spanish Sovereign Bonds: Additional Capital Requirements compared to the unstressed Scenario ${ }^{16}$

EQ3 and EQ4: Thresholds for the ratio of book equity to not-risk weighted total assets of either 3 or $4 \%$. CET1-5.5, CET1-8, CET1-12: Thresholds for the CET1 ratio of 5.5\% (for stress scenarios only), $8 \%$, and $12 \%$. In million Euro.

\begin{tabular}{|l|l|l|l|l|l|}
\hline & EQ3 & EQ4 & CET1-5.5 & CET1-8 & CeT1-12 \\
\hline AUSTRIA & 0 & 0 & 0 & 0 & 9 \\
\hline BELGIUM & 0 & 0 & 0 & 0 & 0 \\
\hline CYPRUS & 0 & 0 & 0 & 0 & 0 \\
\hline FINLAND & 0 & 0 & 0 & 0 & 0 \\
\hline FRANCE & 0 & 0 & 0 & 0 & 0 \\
\hline GERMANY & 81 & 2282 & 0 & 0 & 209 \\
\hline GREECE & 0 & 0 & 0 & 0 & 3 \\
\hline IRELAND & 0 & 0 & 0 & 0 & 0 \\
\hline ITALY & 0 & 91 & 0 & 0 & 328 \\
\hline LUXEMBOURG & 0 & 0 & 0 & 0 & 0 \\
\hline MALTA & 0 & 0 & 0 & 0 & 0 \\
\hline NETHERLANDS & 0 & 35 & 0 & 0 & 0 \\
\hline PORTUGAL & 0 & 17 & 0 & 0 & 4539 \\
\hline SLOVENIA & 0 & 0 & 0 & 0 & 0 \\
\hline SPAIN & 0 & 0 & 2807 & 12101 & 53474 \\
\hline
\end{tabular}

${ }_{16}$ The results for the unstressed scenario for these 49 banks are shown in Table 4A in the Appendix. 